\title{
Intravascular Persistence and Renal Clearance of Dextran of Different Molecular Sizes in Normal Children*
}

\author{
G. ARTURSON, K. GRANATH, and G. GROTTE \\ From the Departments of Paediatric Surgery and Clinical Chemistry, University Hospital, Uppsala, \\ and Pharmacia Ltd., Uppsala, Sweden
}

During the past two decades dextran has been used extensively as a plasma volume expander in adults, while blood loss in the surgery of children is usually replaced by whole blood transfusion. Today the two main indications for using plasma expanders in children are in burns and other emergency situations when blood is not available. There is, however, increasing awareness of the complications of whole blood transfusions (Young, 1964), and there is a possibility that in future plasma expanders will be more frequently used to restore blood volume after moderate blood losses.

In recent years attention has also been drawn to the rheological properties of low molecular weight dextran (Rheomacrodex) which dissolves cell aggregates of sludged blood and promotes capillary flow in certain states of shock (Gelin and Ingelman, 1961). This may be important in neonatal surgery, where the red cell mass is often considerably increased with haematocrit values of $80 \%$ or more.

We have studied the elimination of intravenously administered dextran in 4 infants and children, seeking criteria for a suitable molecular composition of plasma expanders for use in this age-group.

\section{Material and Methods}

We studied 4 normal children, 3 boys and 1 girl, aged 6 days, 3 months, 5 years, and 8 years, who were given an intravenous injection of Rheomacrodex (average molecular weight, $\bar{M}_{\mathrm{w}}$ of about $40,000,>90 \%$ between $15,000$ and 80,000$) 10 \%$ in $0.9 \%$ saline.

A small test dose of $3 \mathrm{ml} . / \mathrm{kg}$. was given to minimize influencing the plasma volume. Venous blood samples were drawn at various times after the injection, and urine was collected in 5 clearance periods from each subject.

The total dextran concentration in serum and urine

\footnotetext{
*A paper read at a meeting of the British Association of Paediatric Surgeons in Edinburgh, July 1965.
}

was determined by the anthrone method (Wallenius, 1954). The molecular weight distribution of dextran in each sample was estimated by a gel filtration method, adapted for micro-amounts (Granath, 1966). By this method dextran is separated according to molecular size in a 'sephadex' column. The method was calibrated by a series of well-defined fractions of dextran.

The endogenous creatinine in blood and urine was determined in a Technicon auto-analyser (method N IIa). The clearance was calculated in the ordinary way, and the values reported were corrected to $1.73 \mathrm{~m}^{2}$ body surface area.

\section{Results}

The results are shown in Fig. 1-7 and Tables I and II. Fig. 1 illustrates the decrease of the total

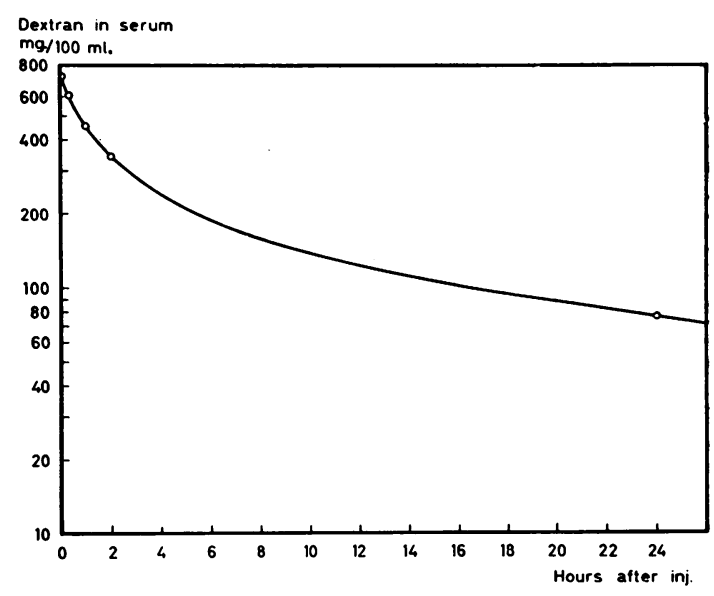

FIG. 1.-The fall in serum dextran concentration after intravenous injection of 'rheomacrodex' (3 ml. $/ \mathrm{kg}$.) in a normal infant aged 6 days. The same case is shown in Fig. 2-6. 


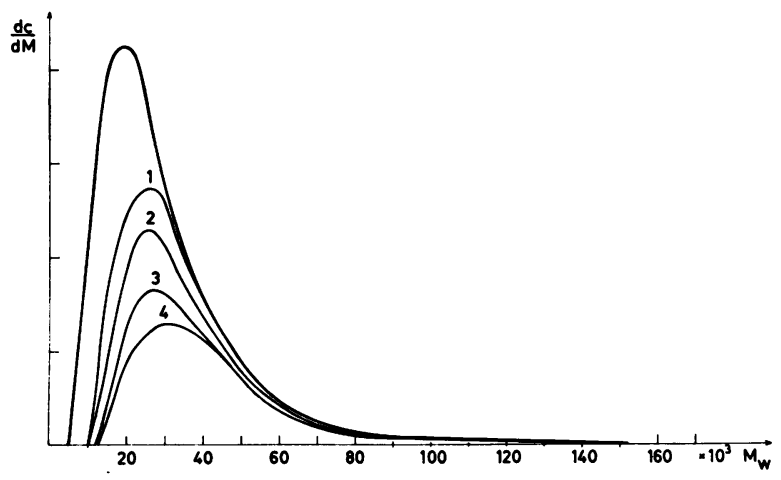

FIG. 2.-Distribution of dextran of different molecular weights in serum at different times after injection. The five curves $0-4$ give results for $0,6,20,40$, and 60 minutes after injection. $C=m g .100 \mathrm{ml}$. serum.

dextran concentration in serum at different times after injection, and in Fig. 2 the changes of the molecular weight distribution of dextran in serum with time after injection are shown. Dextran molecules of molecular weight of about 10,00020,000 leave the circulation fairly rapidly, while the elimination of molecules of molecular weights $>50,000$ is considerably slower (cf. Table I). This results in a shift towards higher molecular weights in serum as illustrated in Fig. 2. From

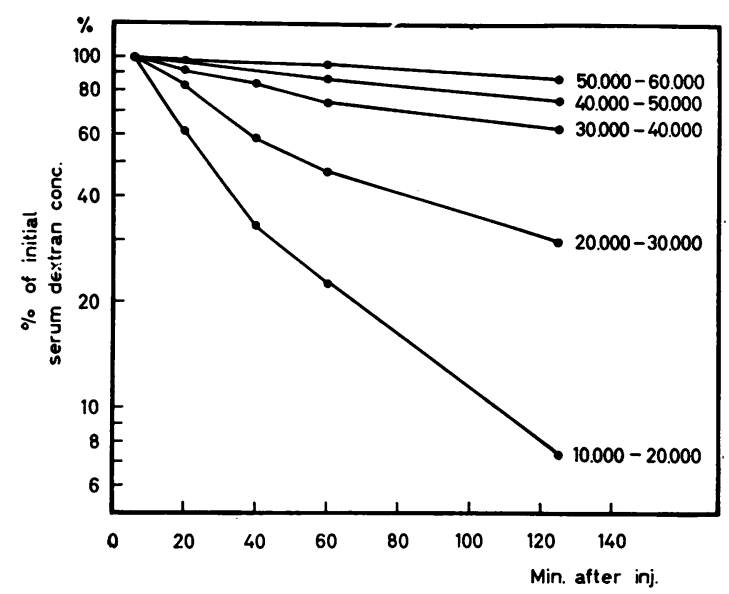

FIG. 3.-The disappearance of dextran of different molecular weights from serum after intravenous administration. these data the average intravascular half-life of the different molecular sizes can be calculated as shown in Fig. 3 (cf. also Table I). The disappearance rates of the various molecular weight classes of dextran from the circulation seem to increase with increasing age of these children.

The excretion of dextran into the urine is shown in Fig. 4-7 and Table II. It is seen that approximately one-third of the injected dose is excreted in 2-3 hours. Corresponding to the shift of the molecular weight distribution of dextran in serum, towards higher molecular weight with time a similar shift was found in urine. In Table II dextran and endogenous creatinine clearance data are shown. Fig. 6 and 7 illustrate dextran clearance as a function of its molecular weight, expressed as a percentage of endogenous creatinine clearance. These preliminary data seem to show a gradual increase of the permeability to macromolecules of the glomerular membranes with increasing age.

\section{Discussion}

As has earlier been shown in animal experiments (cf. Wallenius, 1954; Grotte, 1956; Arturson, 1961) and in studies on adults (cf. Arturson and Wallenius, $1964 a, b)$, the rate of transport of various sizes of dextran molecules across normal capillary membranes is highly dependent on the molecular weight. After intravenous injection small dextran molecules $(<30,000-50,000$ molecular weight) will leave the circulation faster than larger molecules $(>30,000$ 50,000 ) by both the main routes-transport into the extravascular phase and excretion into the urine. 


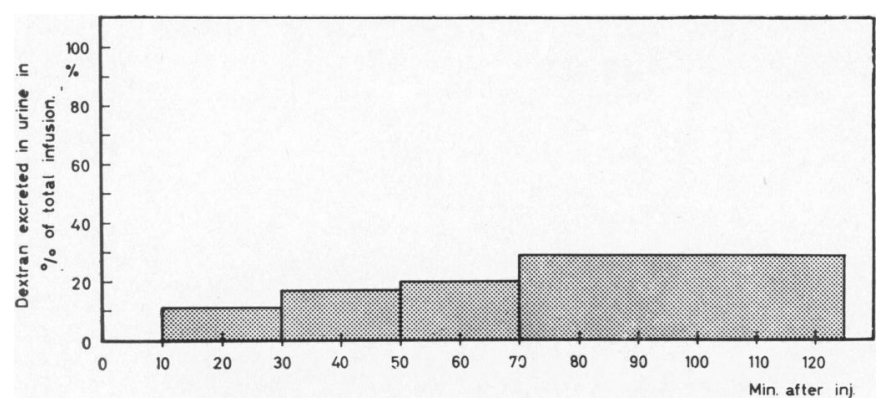

FIG. 4.-Cumulative excretion of dextran into urine after intravenous injection.

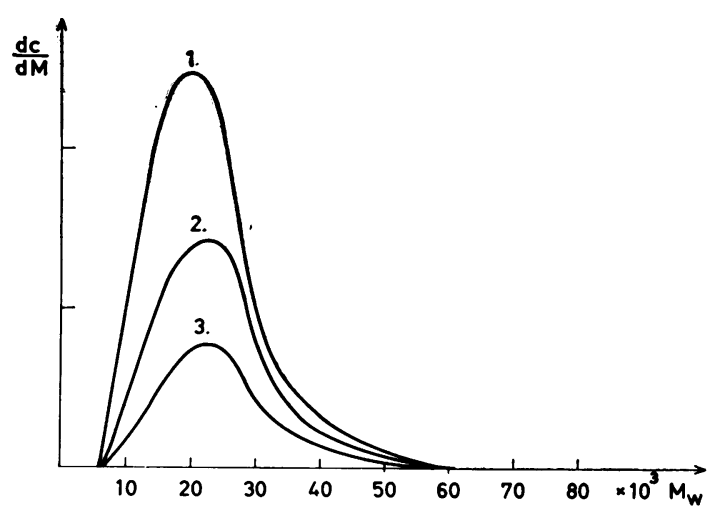

FIG. 5.-Distribution of dextran of different molecular weights in urine. 1. 10-30 min. after injection. 2. 30-50 min. after injection. 3. 50-70 min. after injection. $C=m g . / m i n$.

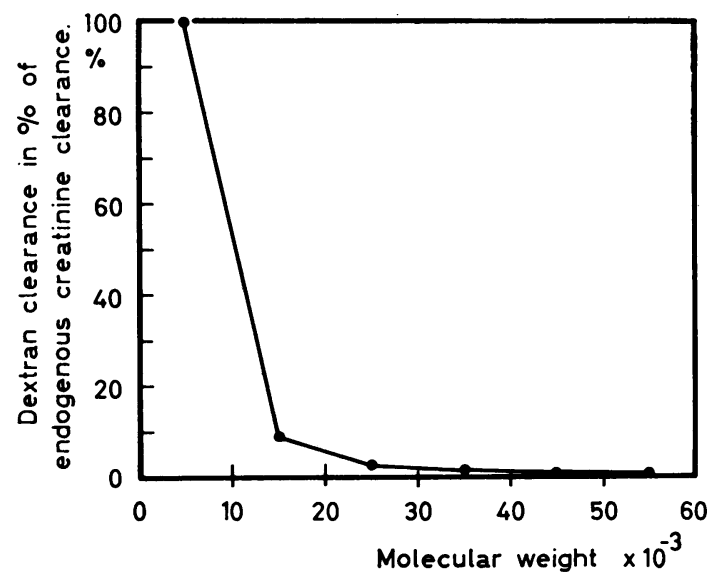

Fig. 6.-Clearance of dextran of different molecular weights as percentage of endogenous creatinine clearance.
The fairly rapid shifts of molecular weight distributions in serum and urine with time was illustrated in these children, as earlier in adults. In 2-3 hours the main part of the dextran molecules still circulating will be of about $30,000-50,000$ molecular weight or more. Smaller molecules have by this time already been excreted into the urine or are still in the extravascular phase on their way back to the circulating blood via the lymphatics (cf. Grotte, Arturson, Areskog, and Jakobsson, 1965). The rates of disappearance of these macro-molecules from the circulating blood seem to increase with increasing age. To some extent this may be explained by the differences in renal clearances in these 4 children. As has been shown by many workers, the inulin and creatinine clearances in the newborn period are about one-third to one-sixth of the values in adults, corrected for body surface area or total body water (cf. Vesterdal, 1959).

These studies (cf. Fig. 7) suggest that there is an

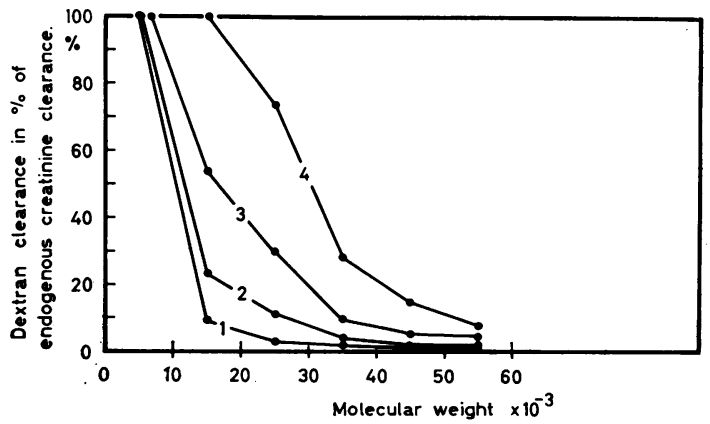

FIG. 7.-Clearance of dextran as percentage of endogenous creatinine clearance in four normal children: Case 1, aged 6 days; Case 2, aged 3 months; Case 3, aged 5 years; and: Case 4 aged 8 years. 
TABLE I

Approximate Intravascular Half-life in Minutes of Different Dextran Molecular Weight Classes

\begin{tabular}{|c|c|c|c|c|c|c|c|}
\hline \multicolumn{4}{|c|}{ Molecular Weight Classes } & Case 1 (Age 6 days) & Case 2 (Age 3 mth.) & Case 3 (Age 5 yr.) & Case 4 (Age 8 yr.) \\
\hline $\begin{array}{l}10,000-20,000 \\
20,000-30,000 \\
30,000-40,000 \\
40,000-50,000 \\
50,000-60,000\end{array}$ & $\begin{array}{l}\cdots \\
\cdots \\
\cdots \\
\cdots\end{array}$ & $\begin{array}{l}\cdots \\
\cdots \\
\cdots \\
\cdots\end{array}$ & $\begin{array}{l}\cdots \\
\cdots \\
\cdots \\
\cdots\end{array}$ & $\begin{array}{r}37 \\
67 \\
245 \\
326 \\
640\end{array}$ & $\begin{array}{r}35 \\
72 \\
207 \\
385 \\
650\end{array}$ & $\begin{array}{r}31 \\
62 \\
144 \\
320 \\
470\end{array}$ & $\begin{array}{r}28 \\
42 \\
70 \\
204 \\
282\end{array}$ \\
\hline
\end{tabular}

TABLE II

Clearances of Dextran and Creatinine in 4 Subjects

\begin{tabular}{|c|c|c|c|c|c|c|c|}
\hline $\begin{array}{c}\text { Case No., Sex, } \\
\text { Weight, } \\
\text { Length, } \\
\text { Age, } \\
\text { Corr. Factor }\end{array}$ & $\begin{array}{c}\text { Time After } \\
\text { Injection for } \\
\text { Blood } \\
\text { Sample } \\
\text { (min.) }\end{array}$ & $\begin{array}{c}\text { Plasma } \\
\text { Dextran } \\
\text { Concentration } \\
\text { (mg./100 ml.) }\end{array}$ & $\begin{array}{l}\text { Length of } \\
\text { Urine } \\
\text { Collection } \\
\text { Period } \\
\text { (min.) }\end{array}$ & $\begin{array}{l}\text { Diuresis } \\
\text { (ml./min.) }\end{array}$ & $\begin{array}{c}\text { Urinary } \\
\text { Dextran } \\
\text { Excretion } \\
\text { (mg./min.) }\end{array}$ & $\begin{array}{l}\text { Dextran } \\
\text { Clearance } \\
\text { (ml./min.) }\end{array}$ & $\begin{array}{l}\text { Creatinine } \\
\text { Clearance } \\
\text { (ml./min.) }\end{array}$ \\
\hline $\begin{array}{c}1 \mathrm{M} \\
2,650 \mathrm{~g} \\
49 \mathrm{~cm} . \\
6 \mathrm{dy} . \\
0 \cdot 18\end{array}$ & $\begin{array}{r}6 \\
20 \\
40 \\
60\end{array}$ & $\begin{array}{l}733 \\
610 \\
459 \\
452\end{array}$ & $\begin{array}{l}10 \\
20 \\
20 \\
20\end{array}$ & $\begin{array}{l}0 \cdot 9 \\
0 \cdot 7 \\
0 \cdot 9 \\
0 \cdot 7\end{array}$ & $\begin{array}{l}1 \cdot 9 \\
7 \cdot 5 \\
4 \cdot 4 \\
2 \cdot 3\end{array}$ & $\begin{array}{l}0.05 \\
0.20 \\
0.18 \\
0.09\end{array}$ & 37 \\
\hline $\begin{array}{c}2 \mathrm{~F} \\
5,670 \mathrm{~g} . \\
51 \mathrm{~cm} . \\
3 \mathrm{mth} . \\
0 \cdot 2\end{array}$ & $\begin{array}{l}10 \\
30 \\
50\end{array}$ & $\begin{array}{l}292 \\
215 \\
205\end{array}$ & $\begin{array}{l}12 \\
20 \\
20\end{array}$ & $\begin{array}{l}0 \cdot 3 \\
0 \cdot 8 \\
1 \cdot 3\end{array}$ & $\begin{array}{l}5 \cdot 1 \\
6 \cdot 3 \\
3 \cdot 5\end{array}$ & $\begin{array}{l}1 \cdot 4 \\
0 \cdot 9 \\
0 \cdot 5\end{array}$ & 60 \\
\hline $\begin{array}{c}3 \mathrm{M} \\
16 \mathrm{~kg} . \\
112 \mathrm{~cm} . \\
5 \mathrm{yr} . \\
0.72\end{array}$ & $\begin{array}{l}37 \\
57 \\
77\end{array}$ & $\begin{array}{l}279 \\
233 \\
201\end{array}$ & $\begin{array}{l}20 \\
20 \\
20\end{array}$ & $\begin{array}{l}4 \cdot 9 \\
5 \cdot 1 \\
4 \cdot 6\end{array}$ & $\begin{array}{r}16 \cdot 7 \\
13 \cdot 3 \\
7 \cdot 4\end{array}$ & $\begin{array}{l}5 \cdot 1 \\
4 \cdot 8 \\
3 \cdot 2\end{array}$ & 21 \\
\hline $\begin{array}{c}4 \mathrm{M} \\
30 \mathrm{~kg} . \\
135 \mathrm{~cm} . \\
8 \mathrm{yr} . \\
1.05\end{array}$ & $\begin{array}{l}41 \\
61\end{array}$ & $\begin{array}{l}183 \\
142\end{array}$ & $\begin{array}{l}20 \\
20\end{array}$ & $\begin{array}{l}4 \cdot 2 \\
7 \cdot 0\end{array}$ & $\begin{array}{l}42 \\
14\end{array}$ & $\begin{array}{l}30 \cdot 0 \\
11 \cdot 9\end{array}$ & 59 \\
\hline
\end{tabular}

increase in permeability of the glomerular membranes with increasing age of infants and children.

\section{Summary}

The intravascular persistence and renal clearance of dextran of different molecular sizes have been studied in 4 children aged from 6 days to 8 years. These results suggest an increase in permeability of the glomerular membranes with increasing age of infants and children.

Technical assistance by Mrs. Mona Eriksson is gratefully acknowledged.

This work was supported by the Swedish Medical Research Council (Project No. W566).

\section{REFERENCES}

Arturson, G. (1961). Pathophysiological aspects of the burn syndrome with special reference to liver injury and alterations of capillary permeability. Thesis. Acta chir. scand., Suppl. 274.

- , and Wallenius, G. (1964a). The intravascular persistence of dextran of different molecular sizes in normal humans. Scand. f. clin. Lab. Invest., 16, 76.

, and $-(1964 \mathrm{~b})$. The renal clearance of dextran of different molecular sizes in normal humans. ibid., 16, 81 .

Gelin, L. E., and Ingelman, B. (1961). Rheomacrodex-a new dextran solution for rheological treatment of impaired capillary flow. Acta. chir. scand., 122, 294.

Granath, K. (1966). To be published.

Grotte, G. (1956). Passage of dextran molecules across the bloodlymph barrier. Thesis. Acta chir. scand., Suppl. 211.

- Arturson, G., Areskog, N. H., and Jakobsson, S. (1965). Extra-vascular circulation of labelled albumin in dog heartlung preparations. Bull. Soc. int. Chir., 24, 97.

Vesterdal, J. (1959). In Die physiologishe Entwicklung des Kindes, ed. F. Linneweh, p. 204. Springer, Berlin.

Wallenius, G. (1954). Renal clearance of dextran as a measure of glomerular permeability. Acta Soc. Med. upsalien., Suppl. 4.

Young, L. E. (1964). Complications of blood transfusion. Ann. intern. Med., 61, 136. 